\title{
IMPROVED PERFORMANCE OF CRANKSHAFT FOR VEHICLE TATRA 12
}

\author{
Ondrej Weis \& Lubos Kroft
}
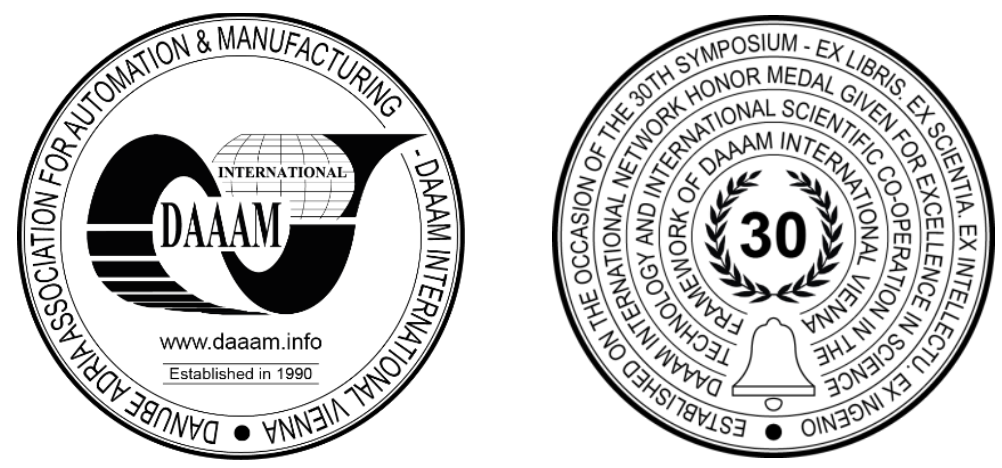

This Publication has to be referred as: Weis, O[ndrej] \& Kroft, L[ubos] (2019). Improved Performance of Crankshaft for Vehicle Tatra 12, Proceedings of the 30th DAAAM International Symposium, pp.1034-1040, B. Katalinic (Ed.), Published by DAAAM International, ISBN 978-3-902734-22-8, ISSN 1726-9679, Vienna, Austria

DOI: $10.2507 / 30$ th.daaam.proceedings.144

\begin{abstract}
This article deals with design modifications and production technology design for one piece production of the crankshaft for Tatra 12 produced in 1923-1934. The importance of manufacturing such components for historical vehicles is growing due to the great interest in these machines. The main aim of this article is to present analysis of original shafts in terms of material, mechanical properties, defects and failures. Given that the original shafts shows significant defects and most cannot be used anymore. It was necessary to determine the cause of these defects and minimalize them in the new design. The production technology also had to be changed and adapted to modern production technologies. The technology is designed for the CTX BETA 1250 turning and milling center.
\end{abstract}

Keywords: crankshaft; material; analysis; production technology; defectoscopy

\section{Intoduction}

This paper presents an analysis of an original crankshaft of Tatra 12 vintage automobile and an approach to fabrication of a new one. Tatra 12 was a Czechoslovak automobile manufactured in 1925-1932. It was built on a backbone chassis with a central tube. The tube, the gearbox and the engine make up the vehicle's load-carrying structure. The car was powered by a four-stroke two-cylinder air cooled engine of "boxer" type (Figure 1) with an OHV valve-train. Restoration of classic cars is a popular pursuit today, which means that both bodywork and drive train need to be rebuilt or restored. Spare parts for this car from the interwar period are not available any more. As a result, some heavily-stressed parts must be substituted with newly-manufactured ones. This may appear to be a simple engineering task. However, replicating a critical component of an engine, especially one which suffered from design flaws, is quite a challenge.

\subsection{Crankshaft - justification of construction design}

As the title of this paper indicates, this work concerned a crankshaft of Tatra 12 automobile. This crankshaft mechanism is very different from the standard configuration in four-stroke engines. Its shape was dictated by the lubrication method. The dry sump engine is fitted with a suction pump which removes oil from the space below the crankshaft mechanism into an external oil reservoir. Hence, the crankcase contains no oil for lubricating and cooling the bearings. Instead of force feed lubrication, a distributor pump is used. It delivers oil via tubes to where it is needed. 
The crankshaft is mounted in roller bearings which require less lubrication. Connecting rod bearings are lead-based and require a constant flow of oil. The flywheel shape of the crankshaft helps lubrication. Oil drips into a groove in the flywheel portion from which it flows into connecting rod bearings driven by centrifugal force. Overall, it is a complex part which must be manufactured to strict quality standards. Another aspect which enters into the design is that it is a key functional part of the engine, transmitting the engine power to the car transmission.

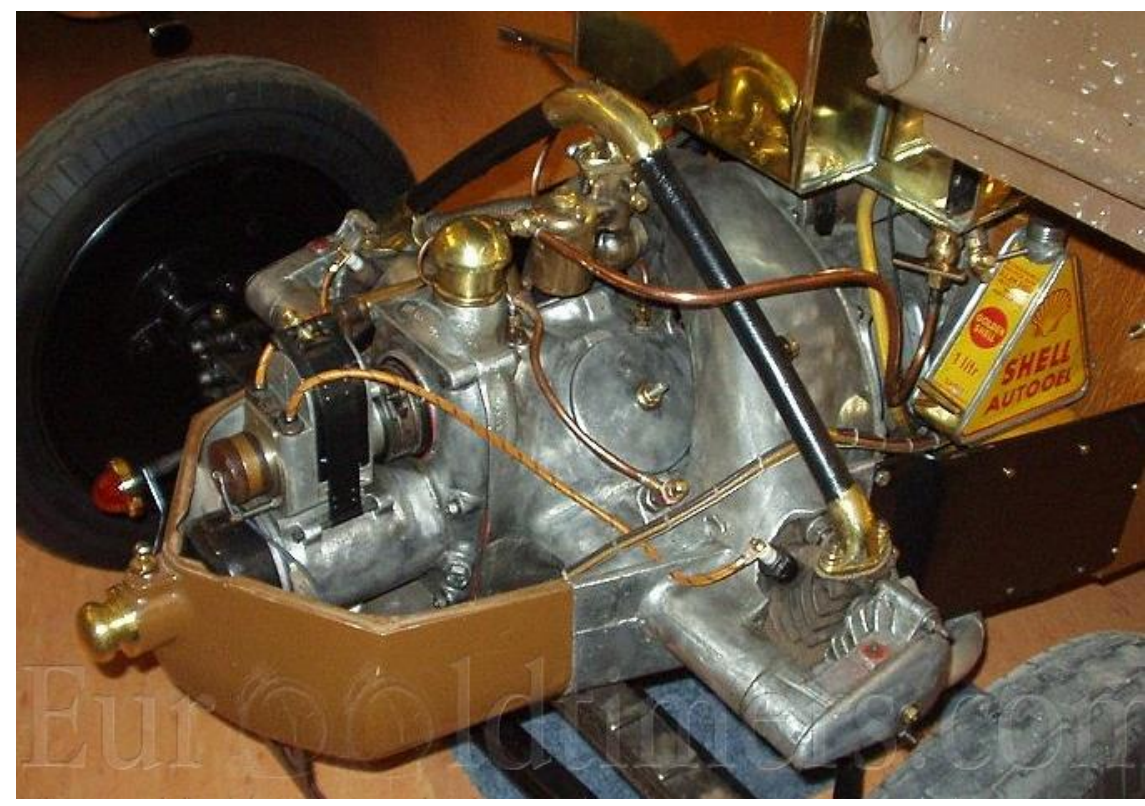

Fig. 1. Engine [1]

\subsection{Crankshaft - technical problems}

The most severe deficiency of this crankshaft is that it exhibits serious defects after decades of service. Among them, the most serious ones are cracks in the most heavily-stressed locations. (Figure 5.) Today, cracks of various sizes are found in a majority of the original shafts of this kind. Another issue is the substantial wear on mating surfaces of connecting rod bearings. All these deficiencies make the original crankshafts unfit for use in restored vehicles.

(Figure 2.)

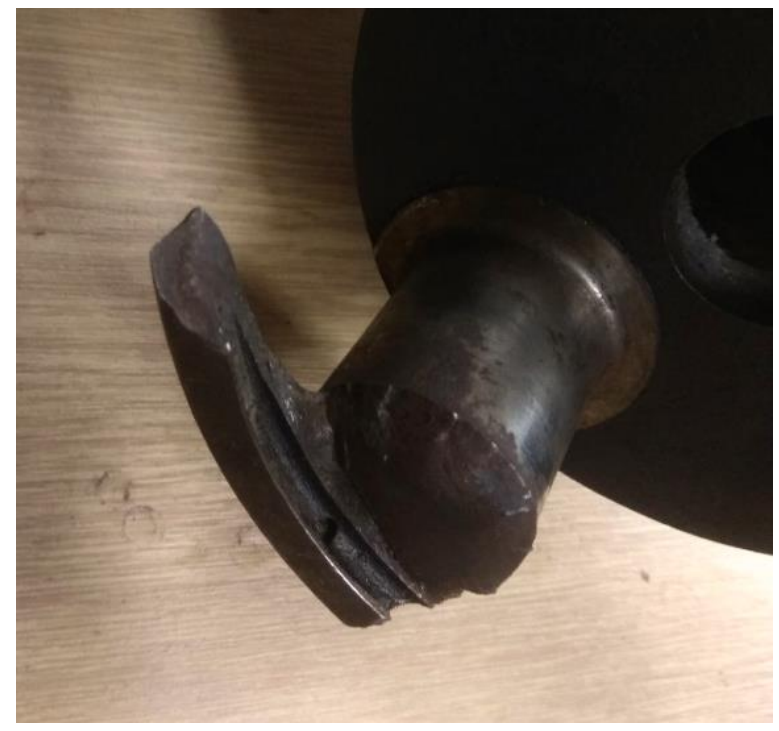

Fig. 2. An example of broken crankshaft

To make matters worse, no documentation is available for making new crankshafts. No drawings for either the crankshaft or even the engine assembly have survived to this day. In addition, no production documents are available. Developing a new production sequence thus becomes difficult, as neither nominal dimensions of the crankshaft nor any tolerances are known. 


\subsection{Crankshaft - innovation}

What an engineer faces is a task that involves a complete design of an engine part. In addition, the part must be fitted into an existing engine in which no adjustments can be made apart from minor restoration work. Therefore, the design and specifications of the crankshaft had to be developed to match the original part. In addition, stress and strain calculations and the production sequence for today's manufacturing equipment had to be developed. The paper presents the core of these development tasks.

\section{Material for production}

Due to the absence of documentation, a new material for production had to be selected. Examination and elimination of defects was another important step in this process.

\subsection{Selection of material}

Material designation on the original crankshafts was the first clue for the selection process. Each crankshaft was marked, once it has been made, with the date of production and the material grade. This particular crankshaft had the ČSN 416320 material grade code, according to a Czech standard. It was verified by measuring the chemical composition of the part using a spectrometer. The identity of the material was thus confirmed. Unfortunately, today's international standards offer no suitable equivalent. Therefore, an adequate substitution was sought.

A mere data sheet was insufficient for this purpose. In order to design the machining sequence, the original material had to be examined to find its heat treatment condition. Its strength was measured and found to be $1100 \mathrm{MPa}$ in all parts of the crankshaft mechanism. This means that the part was probably heat-treated to the upper strength limit throughout the cross-section.

Today's parts of this kind are assembled from several pieces. However, the original crankshaft was a solid machined part with a unique shape. Therefore, a new crankshaft could not have been performed before machining. It had to be machined from a solid bar. The stock weight was approximately $47 \mathrm{~kg}$. The weight of the machined shaft was $6.45 \mathrm{~kg}$. Heat treatment was incorporated after the first rough machining operation in order to reduce the amount of material being heated.

In this case, the large amount of waste material and the machining techniques available in the past lead to a conclusion that roughing had been performed on an annealed stock for the original part. Heat treatment must have been carried out after a large portion of material had been removed, leading to cost savings in series production.

\subsection{Inspection}

The next step involved checking original shafts for defects and potentially critical locations. Magnetic fluorescent particle test was employed for finding surface defects.[4] By examining several shafts, one was able to identify approximate point of crack origin, and therefore the most heavily-stressed locations. (Figure 3.)

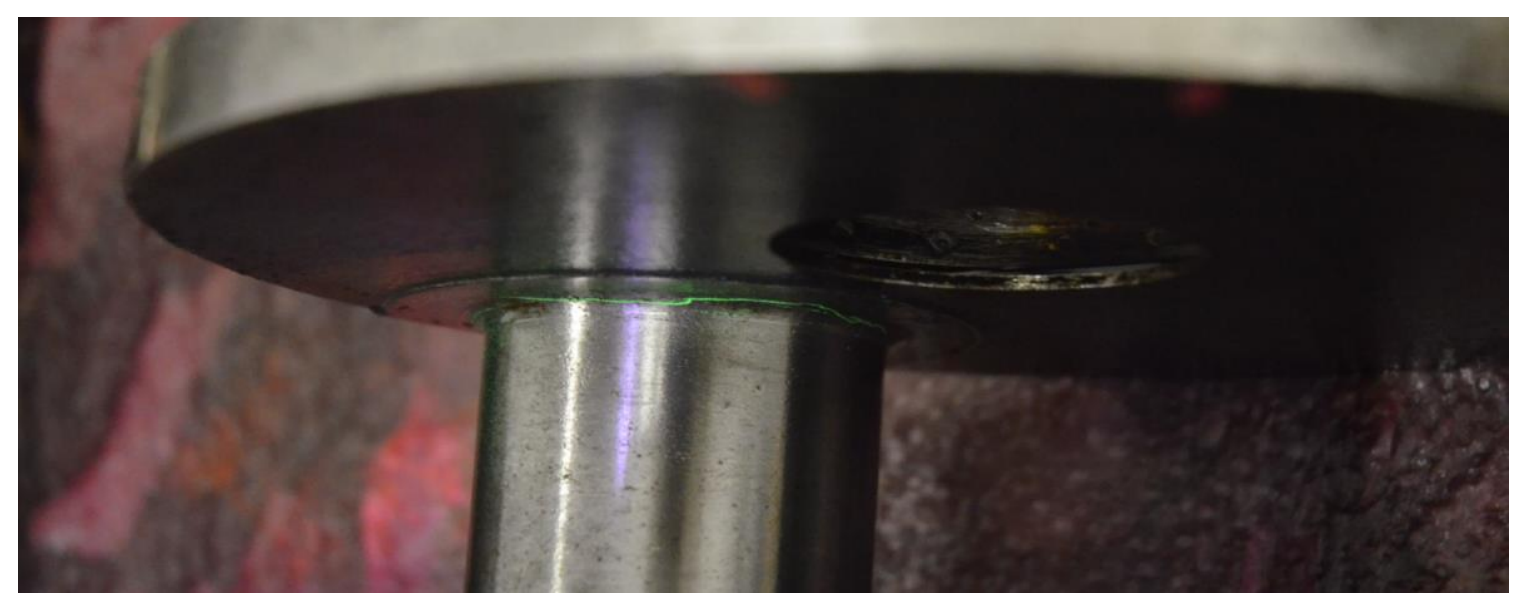

Fig. 3. Crack on original crankshaft

Ultrasonic inspection was used as another technique.[3] As it can detect sub-surface defects, numerous flaws, such as inclusions and various cracks from production, were found. Clearly, the stock was of rather poor quality. 


\subsection{Selection of new material}

After considering all the findings, DIN1.6580 was chosen as the new material for production. Its mechanical properties matched the original material. A very useful aspect was the guaranteed low level of adverse constituents, inclusions and cracks. The stock for job-lot production of a new shaft was heat-treated to $1050 \mathrm{MPa}$.[2] Alloying additions in this material provided sufficient hardening depth. With its carbon content, the material can be induction hardened on mating surfaces of connecting rod bearings without affecting other parts of the shaft.

\section{Design of the crankshaft}

No paper-based documentation was found in collectors' or national technical archives. Original crankshafts were therefore used as sources of data for constructing CAD models and production documents. With the data, one can also conduct stress and other simulations using FEM. Based on their outcomes, some design changes were made to eliminate the causes of defects found in the original parts.

\subsection{CAD data}

As the entire original part was machined, it was not difficult to measure most of its dimensions using ordinary measuring equipment. Transitions of chamfer surfaces or radii had to be measured accurately with a 3D scanner. The 3D scan data (Figure 4.) was input into the CAD model for better accuracy. [6]

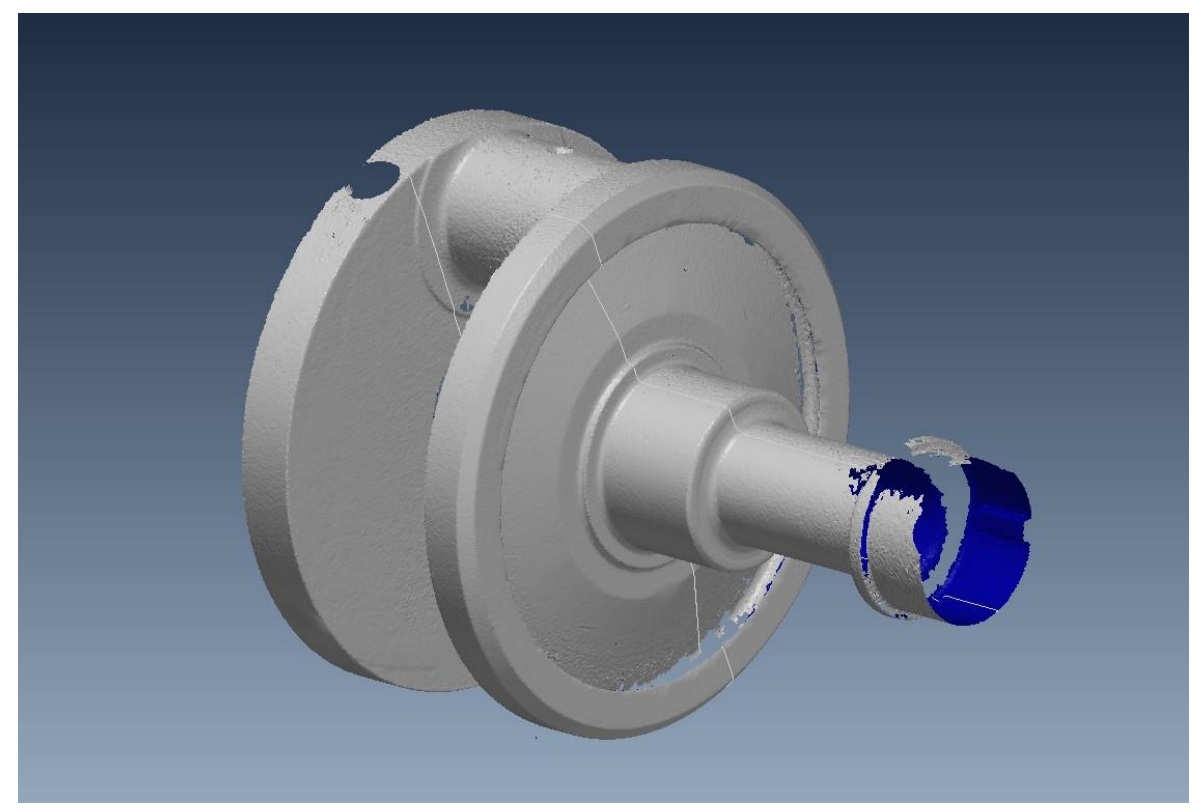

Fig. 4. 3D scan

Unfortunately, some locations were impossible to measure by any method. Damaged shafts had to be cut in appropriate locations to enable inaccessible sections and dimensions to be measured. Thanks to a large number of available damaged parts, complex-shaped features were measured successfully, including shaped undercuts and the lubrication channel.

\subsection{FEM analysis}

It is a widely-used and, with appropriate boundary conditions, rapid and effective method of verification of machine parts. If relevant results are to be obtained, boundary conditions must be specified correctly and in line with anticipated loading on the part in question.

\subsubsection{Loading on the crankshaft}

The load imposed on the crankshaft is complex and of combined nature. The aggregate load consists of torsional, shear and bending components. Bending and shear result from the forces on pistons generated by ignition of the fuel mixture. Torsional loads result from the resistance of the power transmission system. Torsional load is also experienced by bearings on connecting rod journals. Combined loads on the crankshaft are formulated as mathematical expressions in Figure YX. 


\begin{tabular}{|l|l|l|}
\hline \multicolumn{1}{|c|}{ Bending Stress } & \multicolumn{1}{|c|}{ Shear Stress } & \multicolumn{1}{c|}{ Torsion Stress } \\
\hline \multicolumn{1}{|c|}{$\sigma_{o}=\frac{M_{o} c}{J_{z}}$} & \multicolumn{1}{|c|}{$\tau_{s}=\frac{T}{S}$} & \multicolumn{1}{c|}{$\tau_{k}=\frac{M_{k} \cdot \frac{d}{2}}{J_{p}}$} \\
\hline $\begin{array}{l}M_{o} \ldots \text { Bending moment in extreme } \\
\text { locations } \\
J_{z} \ldots \text { Second area moment } \\
c \ldots \text { Distance from the neutral axis }\end{array}$ & $\begin{array}{l}T \ldots \text { Shifting force in extreme } \\
\text { locations } \\
S \ldots \text { Cross section at extreme points }\end{array}$ & $\begin{array}{l}M_{k} \ldots \text { Torque in extreme locations } \\
J_{p} \ldots \text { Polar moment of Area } \\
\frac{d}{2} \ldots \text { Distance from the neutral axis }\end{array}$ \\
\hline \multicolumn{2}{|c|}{ Reduced stress (Guest method) } \\
\hline \multicolumn{2}{|c|}{$\sigma_{\text {red }}=\sqrt{\sigma_{o}^{2}+3 \cdot\left(\tau_{s}+\tau_{k}\right)^{2}}$} \\
\hline
\end{tabular}

Formulas 1, 2 and 3 represent individual bending, shear and torsional components. The combined load is given by Formula 4. The formulas and loads on the crankshaft were derived using the same procedure as in the paper presented in [DAAAM]. With this data, one can specify the boundary conditions for the FEM analysis. A model of the original shaft was the first to be analysed using FEM, although some of its design flaws were readily visible in the unloaded condition. (Figure 5.) [5]

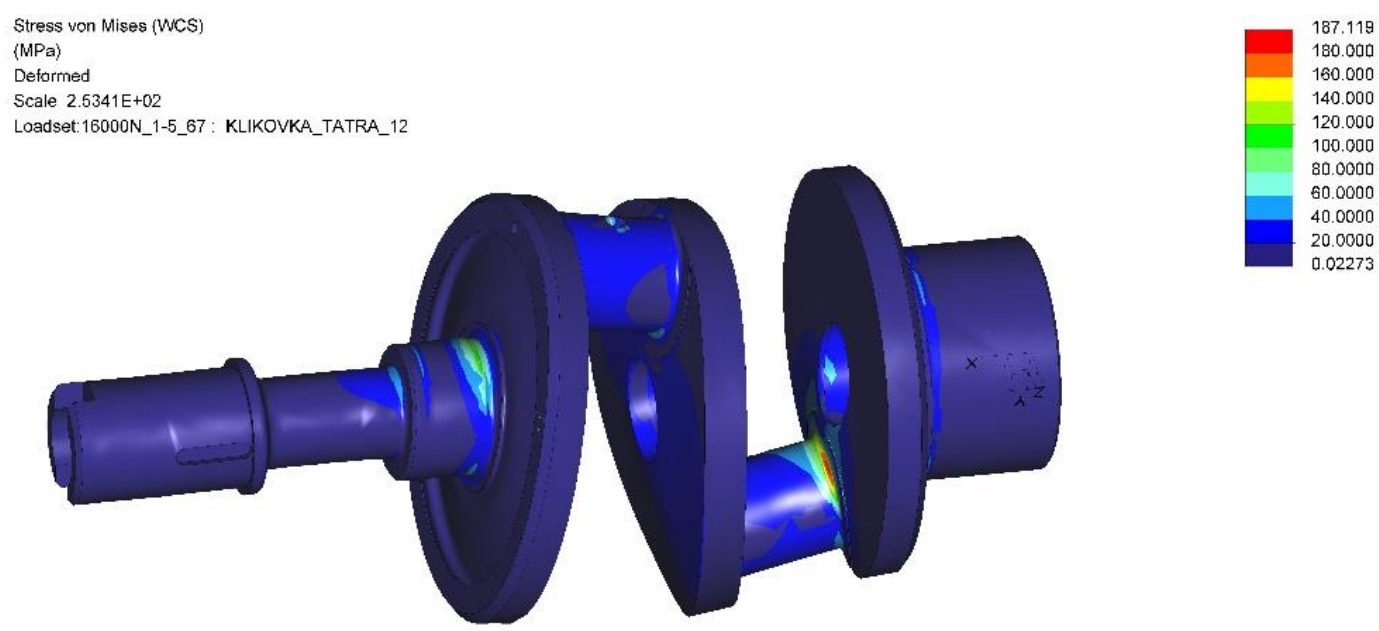

Fig. 5. FEM analysis on original shaft

Discretization and stress and strain calculations revealed that the highest stress was in the location where fatigue cracks had been found. It was not caused by the engine torque but by bending of the crankshaft due to lack of stiffness of its front portion. Its rear part, on the other hand, showed a very high stiffness. (Figure 6.)

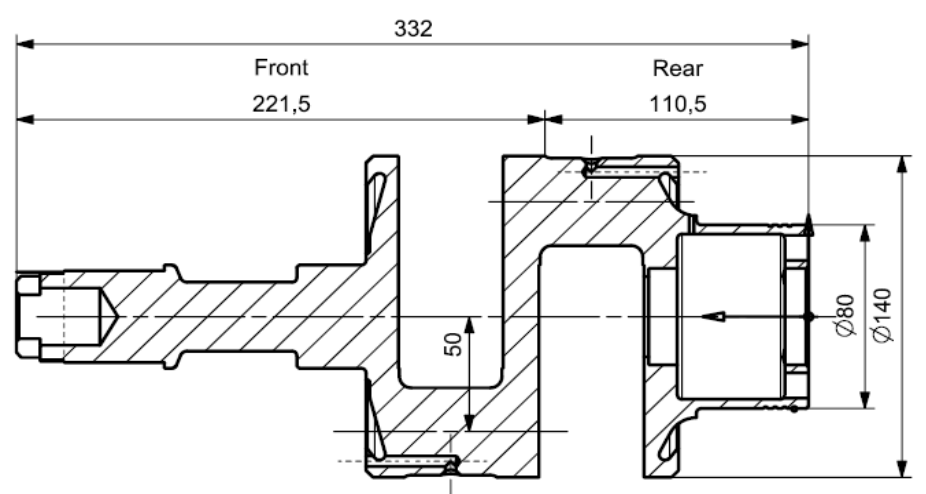

Fig. 6. 


\subsection{Design modification}

Several changes were made to the model of the original crankshaft based on the FEM analysis. Their purpose was to improve the loading conditions on, and therefore extend the life of the shaft. When made from an appropriate and correctly heat-treated material, a new crankshaft should provide much better functional properties.

The first change involved enlarging the radii on the part in order to expand the surface for transmitting the bending load. However, it reduced the stresses in the critical location by no more than several percent. In contrast, eliminating (in fact, reducing the length of) the central hole from the crankshaft proved crucial.

In the original shafts, the entire core was drilled away. The most likely motivation was to make the shaft lighter by removing the portion of material with the poorest mechanical properties. This change reduced the maximum stresses by $20 \%$. This change, combined with larger radii (replacing $\mathrm{R}=2 \mathrm{~mm}$ with $\mathrm{R}=5 \mathrm{~mm}$ ), led to a stress decrease by up to $37 \%$. It is a substantial reduction, which means that one can expect cracking in transition regions of connection rod journals to be eliminated. (Figure 7.)

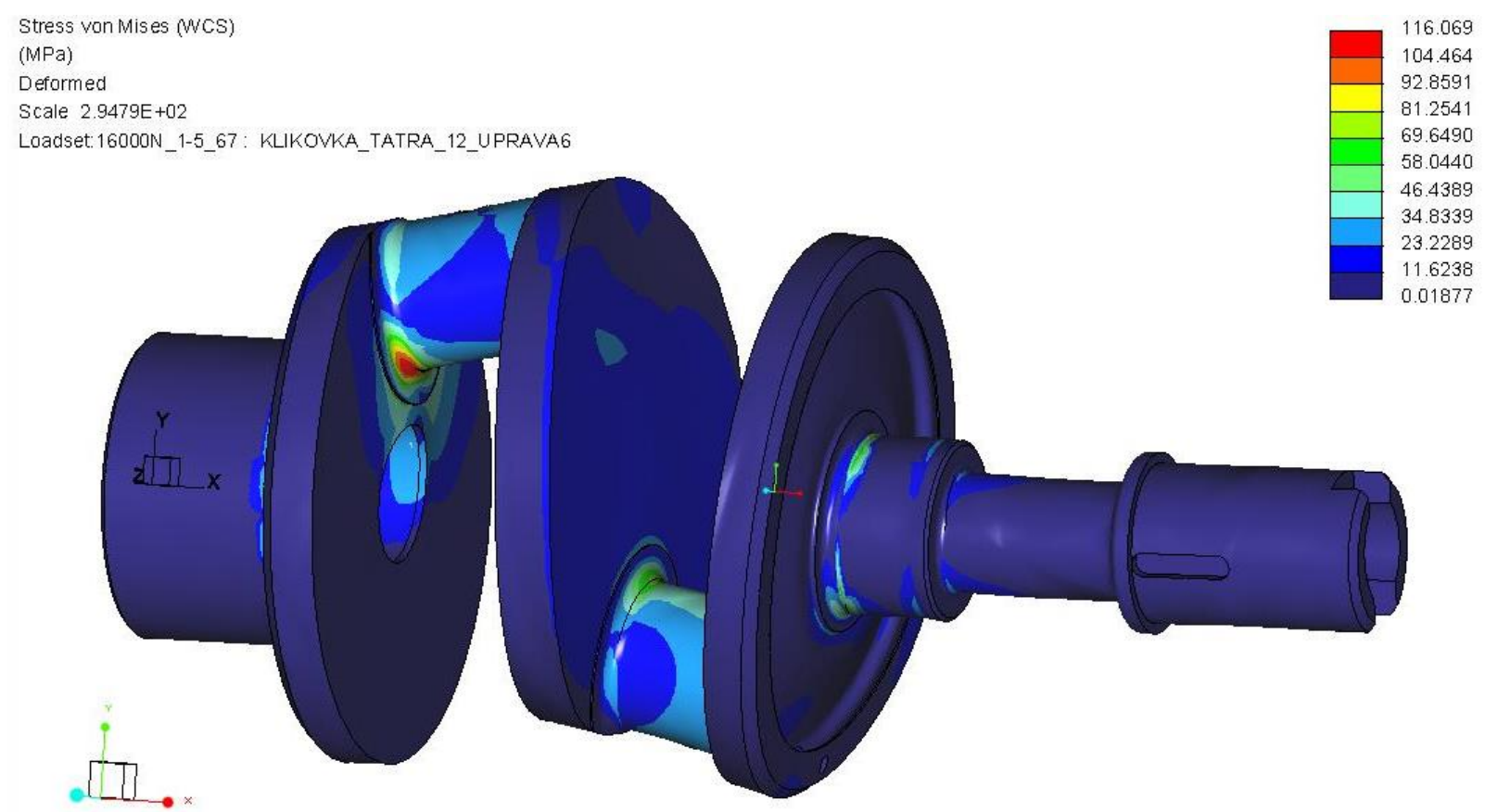

Fig. 7. FEM analysis on changed shaft

\section{Production sequence}

As mentioned in the introduction, one of the goals of this work was to manufacture new crankshafts. Technology has advanced substantially since the time of production of the original crankshafts. The original processes are not available any more. Advanced turning-milling centres were the first choice from the start, so that the entire shaft could be made in one go.

The process was, however, split into several parts. As the part is to be made from a solid stock heat-treated to more than $1000 \mathrm{MPa}$, finding the right production sequence is very important. The risks associated with the production are numerous.

The workpiece may begin to twist, as large volumes of the original stock are removed. This can be controlled by rough machining in multiple stages with stress-relieving annealing between them. Another risk stems from production of shaped undercuts for lubrication of journals for connecting rods. It seems likely that they were originally produced with a special shaped single-purpose tool. As the number of parts will be small, investment in such a tool would not be effective. An available grooving tool will be adjusted for this purpose.

Fabrication of the central hole $\mathrm{D}=35 \mathrm{~mm}$ in diameter and $\mathrm{L}=205 \mathrm{~mm}$ in length posed another difficulty. Design changes led to removal of this feature.

Machining and heat treatment of the entire shaft is time-consuming and still under way. Therefore the full description of the process cannot be given. It will be prepared once the shaft is completed. Additional work should be devoted to evaluating the accuracy and life of the new crankshaft. 


\section{Conclusion}

Crankshafts are complex and complicated parts of vehicles. Since they operate under severe loads, their life and functional properties must not adversely affect the function of the entire engine. When renovating or making new parts for classic cars, one should also consider the original configuration of the entire assembly. All these aspects had to be taken into account in tasks described in this paper.

The susceptibility of the original crankshaft to cracking was the single most important issue. It was caused by minor flaws in the design of the crankshaft and by inclusions which helped crack propagation. These facts were established by comprehensive material and stress analysis of the original crankshaft.

For making a new crankshaft a suitable material had to be identified because there was no equivalent for the steel used for making the original shafts. The substitute was a similar grade with a lower content of undesirable additions. The original process of heat treatment was modified as well. Instead of through quenching, only surface hardening was used in the most heavily-stressed locations of the part. As a result, the core is expected to retain toughness and the risk of cracking should diminish.

The last step in the design process involved FE analysis of both the original and the new modified shaft. For the new version, an up to $37 \%$ reduction in loads acting on critical locations was reported, when compared to the original part. The last step will comprise the manufacture and validation of functional properties of the new crankshaft.

Thanks to modern analytical methods and advanced measuring and production technologies, extended life and improved reliability can be expected in machines which are now only found in museums. This effort has its importance because classic cars are in high demand and the approaches to restoring and maintaining them are applicable to today's technology as well.

\section{Acknowledgments}

This article was created under the project SGS-2019-008: Research and Development for Innovation in the Field of Manufacturing Technology - Machining Technology III.

\section{References}

[1] http://www.eurooldtimers.com/temp/stroj_zoom_5577.jpg

[2] Hamrle, P[avel] \& Hlavac, J[an] (2018). Load Analysis of Crankshaft of TwoPoint Crank Press, Proceedings of the 29th DAAAM International Symposium, pp.0601-0608,B. Katalinic (Ed.), Published by DAAAM International, ISBN 978-3-902734-20-4, ISSN 1726-9679, Vienna, Austria DOI: 10.2507/29th.daaam.proceedings.087

[3] Principle of ultrasonic method http://uvp3d.cz/drtic/?page_id=2076

[4] Magnetic non-destructive test http://www.gammalux.cz/metody.php

[5] LAŠOVÁ, V. Metoda konečných prvků ve výpočtech obráběcích strojů. Západočeská univerzita v Plzni, 2011

[6] URBÁNEK, Aleš. Kontrola součástí pomocí metod reverzního inženýrství [online]. Brno, 2008 [cit. 2019-10-18]. Dostupné z: http://hdl.handle.net/11012/1813. Bakalářská práce. Vysoké učení technické v Brně. Fakulta strojního inženýrství. Ústav strojírenské technologie. Vedoucí práce Jan Zouhar.

[7] HOSNEDL, Stanislav a Jaroslav KRÁTKÝ. Příručka strojního inženýra: obecné strojníčásti. Praha: Computer Press, 1999. Edice strojaře. ISBN 80-7226-055-3.

[8] Baragetti, S.(2015). A Theoretical Method for Structural Design and Analysis of Crankshafts, Int. J.Vehicle Structures \& Systems, 7(3), 92-99.ISSN 0975-3060.doi:10.4273/ijvss.7.3.02 